\title{
Panchayat Raj Institutions as an Instrument for Women Empowerment-A Case Study
}

\author{
Smt.Yamuna.A.Konesar ${ }^{1}$, Dr.Kumar.K.M. ${ }^{2}$ \\ ${ }^{1}$ Research Scholar, Department Of Political Science, G.F.G.College, Bankapur \\ Dist-Haveri, Karnataka State \\ ${ }^{2}$ Research Guide and Associate Professor, Department of Political Science, G.F.G.College, Holehonnur. \\ Dist-Shimoga Karnataka State
}

\begin{abstract}
The concept of empowerment of women is of recent origin. "The word empowerment" has been given currency by UN agencies during recent years. It is increasing of self that the constitutional goal of gender equality cannot be ensured as long as women are not empowered with modern education,employment, and ability to assert their self respect, independence and autonomy to make choices, and opportunities a participate in development activities of the nation

In recent years there have been explicit moves to increase women's political participation. The $73^{\text {rd }}$ and $74^{\text {th }}$ constitutional Amendments in Indian constitution have created space for women in political participation and decision making at the grass root level by providing that $1 / 3$ of the seats in local bodies all over the country be reserved for them with this representation of women in rural local bodies has bocome an area to be explored largly.Women representation in local bodies is an important criterion for assessing their role in politics.

Employment in general and self-employment in particular is intimately connected with women's empowerment. It was attempted to know what measures the Panchayat Raj Institutions had taken to implement employment schemes, especially Swaranjayanti Gram Swaranrozgar Yojana.
\end{abstract}

Keywords: Awareness of self-employment schemes, CONCEPT OF EMPOWERMENT, Constitutional Amendment of India Panchayat Raj Activities about women empowerment, Universe and Methodology.

\section{Introduction}

Panchayat Raj Institutions in India are outcome of natural groupings and associations. Rural local governments existed during the Indus Valley civilization here has been no historical continuity of Panchayat Raj in India. The British India was ruled by a centralized system. After Independence the constituent Assembly set up two committees, one to draw up the union constitution and the second the Provincial committee.In neither of these committees, any mention was made of Panchayat of Gandhian ideals. It was largely through the initiative of late K.Santhanam, who always stood for economic and financial decentralization of powers. The resolution on Panchayat Raj was moved by him in the Constituent Assembly. There was an all-round criticism of overcentralization and denial of village government. It was thus village panchayat found its way into Directive Principles of state policy of the constitution. Article 40 of the constitution reads "The state shall take steps to organize village panchayats and endow them with such powers and authority as may be necessary to enable to function as local self government". The Balwant Rai Mehta Committee (1957) and Ashok Mehta committee (1978) recommended for nominal representation to women in the form of two representatives in each elected body of the PRIs. It was further stated that if no women came forward to become a representative women representation must be ensured by co-opting two women as members for the elected body. The committee on the National Perspective Plan for women 1988 recommended that $30 \%$ seats in local self -government as well as the post of president and vice president of these bodies must be reserved for women

The main objective of introducing Panchayat Raj system is to extend democracy up to grassroots level and ensure involvement of the people in all governmental process and development activities.

\section{The Concept Of Empowerment Of Women}

As per the Universal Declaration of Human Rights "Women's equality in power sharing and active participation in decision making, including decision making in political process at all levels will be ensured for the achievements of the goals of Empowerment.

Empowerment of women is a critical issue that is being debated all over the world. This concept has its root in the women's movement throughout the world and particularly by the Third world feminists it is since the mid 1980s that this term became popular in the field of development, especially with reference to women. Empowerment as a concept was introduced at the International Women's in 1985 at Nairobi .In the present study women empowerment is presented as a concept that includes political level spheres of women's lives 


\section{The $7^{\text {rd }}$ Constitutional Amendment: A New Chapter For Women's Empowerment}

The $73^{\text {rd }} \& 74^{\text {th }}$ amendment to the constitution of India in 1992 was a major step towards democratic decentralization. It has led to greater participation \&empowerment of Schedule Castes/Schedule Tribes and women in PRIs in the country. The reservation of seats in the 1993-94 election has brought in about eight lakhs women into political process in large numbers. Panchayat Raj Institutions have ushered in qualitative changes in the process of governances

\section{IV. Actual Representation Vis-À-Vis Reserved Seats For Women In Panchayat Raj} Institutions In Selected States Of India-2004 ${ }^{(1)}$

\begin{tabular}{|l|l|l|l|}
\hline State & $\begin{array}{l}\text { Reservation for women in } \\
\text { local government } \\
\text { institutions (\%) }\end{array}$ & $\begin{array}{l}\text { Number of women } \\
\text { elected }\end{array}$ & $\begin{array}{l}\text { Representation } \\
\text { Of women (\%) }\end{array}$ \\
\hline Karnataka & $\mathbf{3 3 . 3}$ & $\mathbf{3 7 6 7 6}$ & $\mathbf{4 3 . 6 0}$ \\
\hline Andrapradesh & $\mathbf{3 3 . 3}$ & $\mathbf{7 4 0 1 9}$ & $\mathbf{3 3 . 0 4}$ \\
\hline Assam & $\mathbf{3 3 . 3}$ & $\mathbf{8 7 1 4}$ & $\mathbf{5 0 . 3 8}$ \\
\hline Chhattisgarh & 33.3 & 42914 & 33.75 \\
\hline Gujarat & 33.3 & 42653 & 49.30 \\
\hline Kerala & 33.3 & 5535 & 57.24 \\
\hline Tamilnadu & $\mathbf{3 3 . 3}$ & $\mathbf{2 8 1 2 4}$ & $\mathbf{3 6 . 7 3}$ \\
\hline Uttaranchal & $\mathbf{3 3 . 3}$ & $\mathbf{1 9 2 9 3}$ & $\mathbf{3 7 . 8 5}$ \\
\hline West Bengal & $\mathbf{3 3 . 3}$ & $\mathbf{2 0 5 0 9}$ & $\mathbf{3 5 . 1 5}$ \\
\hline
\end{tabular}

The table shows that women's participation before PRIs was very low in most of the states After Panchayat Raj Institutions it is increasing day by day. They are not only enjoying their one third quotas but in various places they are defeating male members also. They are actively participating in local matters.

V. As Per The Records Of 2005 Indian Women Representation In Politics ${ }^{(2)}$

\begin{tabular}{|c|c|c|c|c|}
\hline S.N & & $\begin{array}{l}\text { Total } \\
\text { seats }\end{array}$ & women & $\begin{array}{l}\% \text { of } \\
\text { women }\end{array}$ \\
\hline 1 & Lok-sabha & 543 & 45 & 8.03 \\
\hline 2 & Rajya-sabha & 242 & 28 & 11.02 \\
\hline 3 & Vidhan-sabha of Karnataka & 224 & 06 & 2.68 \\
\hline 4 & $\begin{array}{l}\text { Total number of zilla panchayat members } \\
\text { in karnataka }\end{array}$ & 1005 & 373 & 37.11 \\
\hline 5 & $\begin{array}{l}\text { Total number of Taluka panchayat } \\
\text { members in karnataka }\end{array}$ & 3683 & 1519 & 41.24 \\
\hline 6 & $\begin{array}{l}\text { Total number of Gram panchayat } \\
\text { members in karnataka }\end{array}$ & 88779 & 38147 & 42.96 \\
\hline
\end{tabular}

It shows women are highly underrepresented in national politics. The success for women in Panchayat Raj institutions is due to reservation for women. 


\section{Objectives Of The Study}

1. To examine the measures undertaken by Panchayat Raj Institutions to improve the basic infrastructure viz, public health, anganawadies, education, water and sanitation.

2. To study whether the PRIs have implemented any employment schemes for the empowerment of women.

3. To know whether the PRIs have played any role in promoting Self Help Groups, and

4. To study the attitudes of Panchayat Raj Institutions members towards women's empowerment.

\section{Universe and Methodology}

The study was conducted in Haveri district of Karnataka. Gram Panchayat, Taluka Panchayat, zilla Panchayat members, secretaries, account writers and SHG members constituted the sample unit. An interview schedule was prepared and administered to respondents. Respondents were contacted at their residence, office, and meetings.

The present Haveri district came into existence on 24-8-1997 upon the bifurcation of the Diistrict of Dharwad.The District has a historical significance and finds references in the ancient Epic Mahabharat .Though the origin of the name is not known with certainty, some local historians opine that in the olden days the place used to be haunted by a lot of snakes (Haavu in kannada the local language) Hence it came to be addressed as Haavu (snake)Eri(came from)In the past ,Haveri was ruled by a number of illustrious rules of Karnataka, district has a number of historical sites \& religious shrines. Culturally, Haveri is well known for folklore, drama, fairs\& festivals. The district has a rich cultural history. It is also well known for religious movements spread through the Bhakti cult. The cult was propagated by the Dasas like Kanakadasa, Sharifsab was born here. The popular kannada TRIPLET poet called "Sarvajna" borned here. The temperature in Haveri district is generally pleasant and healthy. The district is backward in its socio-economic composition of population

\section{Profile of Haveri district Area wise population ${ }^{(3)}$}

\begin{tabular}{|l|l|l|l|l|l|}
\hline S.No & Taluk \\
& Rural\& Urban & \multirow{2}{*}{$\begin{array}{l}\text { Area } \\
\text { (sq.Kms) }\end{array}$} & \multicolumn{2}{|l|}{ As per 2001 P0pulation Census } & \multirow{2}{*}{ Total } \\
\cline { 4 - 5 } & & & Male & Female & \\
\hline $\mathbf{1}$ & Byadgi & 436 & 65765 & 62179 & 127944 \\
\hline $\mathbf{2}$ & Hangal & 773 & 118161 & 42589 & 230750 \\
\hline $\mathbf{3}$ & Haveri & 799 & 130230 & 122117 & 252347 \\
\hline $\mathbf{4}$ & Hirekerur & 806 & 108829 & 103629 & 212458 \\
\hline $\mathbf{5}$ & Ranebennur & 907 & 157019 & 147971 & 304990 \\
\hline $\mathbf{6}$ & Savanur & 539 & 74353 & 69532 & 143885 \\
\hline $\mathbf{7}$ & Shiggaon & 588 & 86112 & 80630 & 166742 \\
\hline $\mathbf{8}$ & Total & 4848 & 740469 & 698647 & 1439116 \\
\hline
\end{tabular}

As noted above, Haveri has 7 taluks \& an area of 4848 sq.kms \& constitutes 2.53 percent of the state's total geographical area. Decentralization of administration has led to the division of the district into 2 revenue sub-divisions, HAVERI and SAVANUR.

\section{Administrative Structure and Number of Panchayat Raj Institutions ${ }^{(4)}$}

\begin{tabular}{|l|l|l|}
\hline S.No & Sub-Revenue & Taluks \\
\hline 1 & Haveri & $\begin{array}{l}\text { Haveri, Byadgi, } \\
\text { Hirekerur, Ranebennur }\end{array}$ \\
\hline 2 & Savanur & $\begin{array}{l}\text { Savanur, Shiggaon, } \\
\text { Hangal }\end{array}$ \\
\hline 3 & Zilla panchayat & Haveri \\
\hline 4 & Number of Taluk panchayats & 07 \\
\hline 5 & Number of Gram panchayats & 208 \\
\hline
\end{tabular}

According to the 2001 census, there were 698 villages \& 7 uninhabited ones in the district. Decentralization has been successfully implemented in the district where the gram, taluk \&district level bodies have been working towards the goal of development with people's participation.PRIs help the women to 
improve their political empowerment level. In my survey 70\% of the women members of GPs and TPs said that to achieve equality in politics, women should make an entry into politics and the problems of women can best be solved only by women. Men cannot understand the women's problems.

\section{Panchayat Raj Institutions Activities About Women Empowerment:}

Empowerment in general and self-employment in particular is intimately connected with women's empowerment. It was attempted to know what measures the PRIs had taken to implement employment schemes, especially swaranjayanti gram swarozgar yojana .It was played a positive role in organizing SHGs by calling meetings, helped in opening account in a bank, providing seed money, bank linkages etc. Many vocational training has been taken place to improve the conditions of the women. Training in skills like free computer education, tailoring garments, knitting, bakery sweets, food for anganavadies, health care, agriculture training, preparation of earth worm compost (Erehulu manure) small scale industrial training etc. Awareness camp for rural women has been taken place to improve the conditions of the women as well as the youths.

X. Awareness of self-employment schemes ${ }^{\left(5^{5}\right.}$

\begin{tabular}{|c|c|c|c|c|c|c|c|c|c|}
\hline \multirow{2}{*}{ schemes } & \multicolumn{3}{|c|}{ Panchayat Raj Members } & \multicolumn{3}{c|}{$\begin{array}{c}\text { Self Help group } \\
\text { members }\end{array}$} & \multicolumn{4}{c|}{ Total } \\
\cline { 2 - 10 } & No & $\%$ & Total & No & $\%$ & Total & No & $\%$ & Total \\
\hline SGSY & 42 & 68 & 62 & 68 & 63 & 108 & 110 & 65 & 170 \\
\hline Indira Awaz Yojana & 43 & 69 & 62 & 50 & 46 & 108 & 93 & 55 & 170 \\
\hline Ambedkar Yojana & 40 & 64 & 62 & 60 & 55 & 108 & 100 & 59 & 170 \\
\hline Ashraya Yojana & 39 & 63 & 62 & 60 & 55 & 108 & 100 & 59 & 170 \\
\hline PMRY & 42 & 68 & 62 & 30 & 28 & 108 & 72 & 42 & 170 \\
\hline Navagram Yojana & 62 & 100 & 62 & 108 & 100 & 108 & 100 & 59 & 170 \\
\hline Kooligagi Kalu & 62 & 100 & 62 & 108 & 100 & 108 & 100 & 59 & 170 \\
\hline Stree Shakti & 60 & 96 & 62 & 100 & 95 & 108 & 160 & 90 & 170 \\
\hline
\end{tabular}

Data presented in table shows that an overwhelming majority of both PRI members and SHG members were aware of schemes meant for women and empowerment. It could be clearly stated that a majority of the rural women, under the investigation, had some idia of schemes meant for their upliftment.

One of the basic responsibilities of panchayats is to promote Self-Help Groups, which have come to stay in rural areas as the main women's organizations for empowerment.

It should be noted that women's empowerment depends upon the extent to which basic infrastructure such as schools, public health, anganawadies and water and sanitation are provided to rural women. In my survey I have come to know that all are functioning well as per people's expectations. PRIs office bearers supervise and check duties, attendance of school teacher's public health and anganawadi staff. There were overhead tanks and water stands, but water is not regularly stored due to load shedding.

\section{Conclusion}

Majority of the members reported that there has been improvement in the panchayat administration due to $73^{\text {rd }}$ amendment. They also feel that it has improved the status of women. The women members also stated that there were no difficulties due to male -dominated society .The situation is changing very fast. Some of the women chairmen have done commendable job. They are marching on the challenging road towards empowerment.

It could be concluded that the new PRIs has played relatively positive role in providing infrastructure, employment opportunities and promoting SHGs. Consequently, there is a change in the attitudes of rural women who are becoming conscious of education, employment etc. But income generating schemes have not been implemented to the satisfaction of the beneficiaries.

References 